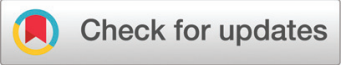

Cite this: DOI: 10.1039/c9fo00491b

\title{
Yerba mate aqueous extract improves the oxidative and inflammatory states of rats with adjuvant-induced arthritis
}

\author{
Vanesa Gesser Correa, ${ }^{a}$ Anacharis B. de Sá-Nakanishi, ${ }^{b}$ \\ Geferson de Almeida Gonçalves, ${ }^{a}$ Lillian Barros, (D) ${ }^{c}$ Isabel C. F. R. Ferreira, (iD c \\ Adelar Bracht (iD a and Rosane M. Peralta iD *a,b
}

\begin{abstract}
Healthy and adjuvant-induced arthritic rats were treated for 23 days with daily doses of 400 and $800 \mathrm{mg}$ $\mathrm{kg}^{-1}$ Ilex paraguariensis extract. This treatment (a) diminished the ROS levels in the liver and brain, (b) decreased oxidative protein and lipid damage in liver and brain, (c) increased the plasma antioxidant capacity, (d) increased the GSH levels and the GSH/GSSH ratio in both the liver and the brain, (e) almost restored the enzymatic activities linked to the metabolism of GSH-GSSG, and ( $f$ ) reversed the modified activities of xanthine oxidase, superoxide dismutase and catalase. The anti-inflammatory actions (firstly) and the antioxidant actions (in the second place) of the yerba mate constituents (e.g., chlorogenic acid derivatives) are the causes of these beneficial effects. Daily ingestion of traditional yerba mate beverages may be effective in attenuating the symptoms of inflammatory diseases, especially in older adults.
\end{abstract}

Received 7th March 2019 Accepted 23rd July 2019

DOI: 10.1039/c9fo00491b

rsc.li/food-function chemical composition with compounds belonging to several classes. An investigation of our research group, in which the compositions of the leaves, stems and whole plant of yerba mate were characterized, revealed at least five sugars, five organic acids, eighteen fatty acids, one tocopherol, nine hydroxycinnamoyl derivatives (phenolic acids) and two flavonols. ${ }^{4}$ The leaf extract revealed the highest antioxidant activity, correlating with its highest levels of phenolic compounds. The stem extracts, however, presented the highest anti-inflammatory potential as inferred from its NO production inhibitory activity and the highest cytotoxic properties. Additionally, yerba mate also contains vitamins (A, B complex, C and E) and tannins and triterpenic saponins. ${ }^{1,2}$ It is not certain if all these substances are absorbed when yerba mate infusions are consumed because digestion and fermentation in the gastrointestinal tract could eventually cause substantial modifications. A recent study of our group, in which yerba mate extracts were submitted to in vitro digestion coupled to colonic fermentation, allows to infer about the gastrointestinal events prior to the absorption of the phenolic compounds that are listed in Table $1 .^{5}$ Digestion and fermentation in the gastrointestinal tract apparently causes pronounced decreases in the 3,5-Odicaffeoylquinic and 5-O-caffeoylquinic acid (chlorogenic acid) contents. Other compounds, however, such as 3-O-caffeoylquinic acid (neochlorogenic acid), 4-O-caffeoylquinic acid (cryptochlorogenic acid) and salvianolic acid I are only minimally affected. This corroborates the general notion that the functional properties of the yerba mate constituents are largely Brazil

${ }^{b}$ Department of Biochemistry, State University of Maringa (UEM), 87020-900 Paraná, Brazil.E-mail: rosanemperalta@gmail.com,rmperalta@uem.br ${ }^{c}$ Centro de Investigação de Montanha (CIMO), Instituto Politécnico de Bragança, Campus de Santa Apolónia, 5300-253 Bragança, Portugal 
Table 1 Daily doses of phenolic compounds administered to the control and arthritic rats, recalculated from the corresponding contents of the yerba mate aqueous extract reported in a previous work ${ }^{5}$

\begin{tabular}{llc}
\hline & \multicolumn{2}{c}{ Daily dose of each compound $\left(\mathrm{mg} \mathrm{kg}^{-1}\right)$} \\
\cline { 2 - 3 } Compound & $400 \mathrm{mg} \mathrm{kg}^{-1}$ dose & $800 \mathrm{mg} \mathrm{kg}^{-1} \mathrm{dose}^{-}$ \\
\hline 3-O-Caffeoylquinic acid & 5.12 & 10.24 \\
4- $O$-Caffeoylquinic acid & 5.55 & 11.10 \\
5- $O$-Caffeoylquinic acid & 8.37 & 16.74 \\
Caffeic acid hexoside & 0.23 & 0.46 \\
Caffeic acid derivative & 1.43 & 2.86 \\
3,4- $O$-Dicaffeoylquinic acid & 1.84 & 3.68 \\
3,5-O-Dicaffeoylquinic acid & 7.74 & 15.48 \\
4,5-O-Dicaffeoylquinic acid & 2.58 & 5.16 \\
Quercetin 3- $O$-rutinoside & 2.24 & 4.48 \\
Salvianolic acid & 11.78 & 23.56 \\
& & \\
\hline
\end{tabular}

maintained after digestion in the intestinal tract. ${ }^{5}$ However, after absorption, many transformations occur in the tissues, including hydrolysis by esterases which produces caffeic and quinic acids, $O$-methylation that leads to the production of ferulic acid derivatives and conjugations to glucuronic acid and sulfate. ${ }^{6,7}$

Among the functional properties of yerba mate, the combined antioxidant and anti-inflammatory actions could be useful in attenuating the symptoms of diseases in which inflammation and oxidative stress are both prominent. One such disease is rheumatoid arthritis, which is characterized by a chronic inflammation that primarily affects the small joints of hands and feet. The disease involves well known immunological events, such as participation of T cells, B cells, macrophages and pro-inflammatory cytokines, and, in their progression, an increased oxidative stress in the lesion sites. ${ }^{8}$ In addition to affecting the articular cartilage, rheumatoid arthritis also evokes marked inflammatory responses and oxidative stress in other organs, such as vascular tissue, liver, brain and the heart. ${ }^{9-12}$ In principle, the pronounced antioxidant activity of yerba mate should be able to attenuate the oxidative stress caused by rheumatoid arthritis. ${ }^{4,5}$ Similarly, yerba mate should equally be able to attenuate the inflammatory state if one takes into account its well documented anti-inflammatory activity. ${ }^{13-15}$ Considering the antioxidant and anti-inflammatory properties of yerba mate, we decided to investigate the effects of a hot water aqueous extract on both the oxidative and inflammatory states of rats with arthritis induced by the complete Freund's adjuvant as a continuation of our previous investigations on the chemical composition of hot and cold water extracts of this plant. ${ }^{4,5}$ The hot water extract corresponds to the traditional beverage known as "chimarrão" in Brazil and simply "mate" in Spanish speaking countries. Adjuvant-induced arthritis is an experimental immuno-pathology in rats that shares many features of human rheumatoid arthritis and is often used as a model for this disease. ${ }^{10,16,17}$ The study aims at providing information about the possible benefits of the continuous and regular ingestion of yerba mate infusions by individuals suffering from or predisposed to rheumatoid arthritis.

\section{Materials and methods}

\section{Chemicals}

Dinitrophenylhydrazine (DNPH), 2'7'-dichloro-fluorescein diacetate (DCFA-DA), oxidized dichloro-fluorescein (DCF), $1,1^{\prime}, 3,3^{\prime}$-tetraethoxy-propane, horse-radish peroxidase (HRP), $o$-phthalaldehyde (OPT), reduced glutathione (GSH), oxidized glutathione (GSSG), glutathione reductase, 6-hydroxy-2,5,7,8tetramethylchromane-2-carboxylic acid (Trolox) and Freund's adjuvant were purchased from Sigma-Aldrich (St Louis, MO, USA). The commercial kit for the albumin assay was purchased from Gold Analisa Diagnostica Ltda (Belo Horizonte, Brazil). Water was treated in a Milli-Q water purification system (TGI Pure Water Systems, Greenville, SC, USA). All other chemicals were of analytical grade.

\section{Preparation of the Ilex paraguariensis extract}

Raw yerba mate was obtained from a reliable commercial source and producer in Southern Brazil. The extract was prepared in the same way as the traditional beverage ("chimarrão") in Brazil. For preparing, $1.5 \mathrm{~L}$ of water at $80{ }^{\circ} \mathrm{C}$ was added to $85 \mathrm{~g}$ of yerba mate. After $5 \mathrm{~min}$, the mixture was filtered using a vacuum pump. The extract was lyophilized and kept at $-20^{\circ} \mathrm{C}$ until use. Characterization of the extract in terms of its composition in phenolic bioactives was done in a previously published work. ${ }^{5}$ As detailed in the next subsection, extract doses of 400 and $800 \mathrm{mg} \mathrm{kg}^{-1}$ were administered daily to healthy and arthritic rats. Table 1 presents a list of the corresponding daily doses of phenolic bioactives, recalculated from the data obtained in our previous work. ${ }^{5}$

\section{Animals and treatment}

Male Holtzman rats were fed ad libitum with a standard laboratory diet (Nuvilab, Colombo, Brazil) maintained under standard laboratory conditions at a temperature of $24 \pm 3{ }^{\circ} \mathrm{C}$ under a regulated $12 \mathrm{~h}$ light/dark cycle. For the induction of arthritis, animals weighing $180-210 \mathrm{~g}$ were injected in the left hind paw with $0.1 \mathrm{~mL}(500 \mu \mathrm{g})$ of Freund's complete adjuvant (heat-inactivated Mycobacterium tuberculosis, derived from the human strain H37Rv), suspended in mineral oil at a concentration of $0.5 \%(\mathrm{w} / \mathrm{v}){ }^{17}$ Rats of similar weights were injected with the mineral oil and served as controls. All procedures were previously approved by the Ethics Committee for Animal Experimentation of the State University of Maringá (Protocol no. 6168170117).

The animals were divided into 7 groups: (1) group C were healthy animals (controls); (2) group C-T 400 were healthy animals treated with $400 \mathrm{mg} \mathrm{\textrm {kg } ^ { - 1 }}$ Ilex paraguariensis (yerba mate) extract; (3) group C-T 800 were healthy animals treated with $800 \mathrm{mg} \mathrm{kg}^{-1}$ yerba mate extract; (4) group AIA were the arthritic rats; (5) group AIA-T 400 comprised the arthritic rats treated with $400 \mathrm{mg} \mathrm{kg}^{-1}$ yerba mate extract; (6) group AIA-T 800 comprised the arthritic rats treated with $800 \mathrm{mg} \mathrm{kg}^{-1}$ yerba mate extract; and (7) group AIA-ibuprofen were arthritic rats treated with ibuprofen ( $35 \mathrm{mg} \mathrm{kg}^{-1}$, positive controls). 
For each treatment, the rats received the extract or ibuprofen once a day by oral administration (gavage) for 5 days prior to the induction of arthritis and for additional 18 days after initiating the induction. The treated controls received the same doses for 23 days. Non-treated animals, healthy or arthritic, received water for 23 days.

\section{Blood collection and tissue preparation}

Rats fasted for 18 hours were anesthetized by intraperitoneal injection of sodium thiopental (100 $\mathrm{mg} \mathrm{kg} \mathrm{kg}^{-1}$ ) plus lidocaine $\left(10 \mathrm{mg} \mathrm{kg}^{-1}\right)$. After exposition of the peritoneal cavity by laparotomy, blood was collected from the cava vein and poured into tubes containing an anticoagulant $\left(100 \mathrm{IU} \mathrm{mL}^{-1}\right.$ of sodium heparin). Subsequently, the samples were centrifuged at $1000 \mathrm{~g}$ for $10 \mathrm{~min}$ for separating the plasma fraction. ${ }^{18}$

After blood collection, the brain and the liver were immediately removed, freeze-clamped, and stored in liquid nitrogen. Subsequently, the tissues were homogenized separately in a van Potter homogenizer with 10 volumes of ice-cold $0.1 \mathrm{M}$ potassium phosphate buffer ( $\mathrm{pH}$ 7.4) and aliquots were separated for use as total homogenates. The remaining fractions were centrifuged at $11000 \mathrm{~g}$ for $15 \mathrm{~min}$, and the supernatants separated as the soluble fractions of the homogenates. ${ }^{18}$

Protein concentration was measured with the FolinCiocalteu reagent, using bovine serum-albumin as a standard. $^{19}$

\section{Oxidative state indicators and antioxidant capacity}

Levels of ROS were quantified in the supernatants of the homogenates by spectrofluorimetry using 2',7'-dichlorofluorescein diacetate (DCFH-DA). ${ }^{20}$ A standard curve with oxidized dichlorofluorescein (DCF) was used to express the results as nmol mg ${ }^{-1}$ protein. ${ }^{18}$

Reduced glutathione (GSH) and oxidized glutathione (GSSG) levels were measured in the total homogenate. Both analyses were done spectrofluorimetrically (excitation at $350 \mathrm{~nm}$ and emission at $420 \mathrm{~nm}$ ) by means of the $o$-phthalaldehyde (OPT) assay, as described previously. ${ }^{21}$ Fluorescence was estimated as GSH. For the GSSG assay, the sample was previously incubated with $10 \mathrm{mM} \mathrm{N}$-ethylmaleimide and subsequently with a mixture containing $1 \mathrm{M} \mathrm{NaOH}$ and $0.4 \mu \mathrm{M}$ OPT to detect the fluorescence. Standard curves were prepared with GSH or GSSG, and the contents were expressed as nmol $\mathrm{mg}^{-1}$ protein.

\section{Enzymatic activities}

Enzymatic activities were assessed in the homogenate supernatant. The catalase (CAT) activity was estimated by measuring changes in absorbance at $240 \mathrm{~nm}$ using $\mathrm{H}_{2} \mathrm{O}_{2}$ as the substrate and expressed as $\mu \mathrm{mol} \mathrm{min}^{-1}$ (mg protein $)^{-1} .^{22}$ The glutathione reductase (GR) activity was estimated by measuring changes in absorbance at $340 \mathrm{~nm}$ using NADPH and GSSG as substrates and expressed as nmol $\mathrm{min}^{-1}$ (mg protein $)^{-1} \cdot{ }^{22}$ The superoxide dismutase (SOD) activity was estimated by its capacity to inhibit the pyrogallol auto-oxidation in an alkaline medium. The latter was measured spectrophotometrically at
$420 \mathrm{~nm}^{23}$ One SOD unit was considered the quantity of enzyme that was able to promote $50 \%$ inhibition, and the results were expressed as units per $\mathrm{mg}$ protein. The glutathione peroxidase (GPx) activity was estimated by measuring changes in absorbance at $340 \mathrm{~nm}$ due to NADPH oxidation in the presence of $\mathrm{H}_{2} \mathrm{O}_{2}, \mathrm{GSH}$ and glutathione reductase and expressed as nmol $\min ^{-1}$ (mg protein $)^{-1} \cdot{ }^{24}$ The xanthine oxidase (XO) activity was measured as the increase in absorbance at $295 \mathrm{~nm}$ due to uric acid formation, and the rates were expressed as nmol $\min ^{-1}(\mathrm{mg} \text { protein })^{-1} \cdot{ }^{25}$

The myeloperoxidase activity (MPO) was determined by the $o$-dianisidine dihydrochloride- $\mathrm{H}_{2} \mathrm{O}_{2}$ method. ${ }^{26}$ The change in absorbance at $460 \mathrm{~nm}$ was measured for 1 minute. The activity was calculated from the molar extinction coefficient $(\varepsilon=1.13 \times$ $\left.10^{4} \mathrm{M}^{-1} \mathrm{~cm}^{-1}\right)$, and the activities were expressed as nmol $\min ^{-1}(\mathrm{mg} \text { protein })^{-1}$.

\section{Oxidative injury parameters}

The TBARS (thiobarbituric acid reactive substances) method was used to evaluate lipid peroxidation by oxidative damage. A standard curve, prepared with 1',3,3'-tetraethoxypropane, was used to evaluate the number of lipoperoxides, and the values were expressed as nmol $\mathrm{mg}^{-1}$ protein. ${ }^{27}$ Protein carbonyls were measured in plasma and in liver and brain homogenates using 2,4-dinitrophenylhydrazine $(\mathrm{DNPH})\left(\varepsilon_{370}=2.2 \times 10^{4} \mathrm{M}^{-1}\right.$ $\mathrm{cm}^{-1}$ ), and the values were expressed as nmol mg ${ }^{-1}$ protein for the plasma and $\mathrm{nmol} \mathrm{mg^{-1 }}$ protein for the liver and brain. ${ }^{28}$

\section{Plasma redox and liver and kidney damage indicators}

The antioxidant capacity of the plasma was estimated as the ferric ion antioxidant reducing power (FRAP) by spectrophotometry. ${ }^{29}$ The standard curve was prepared with Trolox (6-hydroxy-2,5,7,8-tetramethyl-chroman-2-carboxylic acid), and the activity was expressed as mmol of Trolox equivalents per $\mathrm{mL}$ of plasma.

Albumin, protein, aspartate aminotransferase (AST) activity and alanine aminotransferase (ALT) activity were measured in the plasma using commercial kits (Gold Analisa ${ }^{\circledR}$ ). Globulin levels were calculated as the difference between the total protein and albumin concentrations.

\section{Leukocytes, secondary lesions and paw volume}

The inflammatory response induced by Freund's complete adjuvant was inferred from the number of leukocytes in the femorotibial joint cavities of the legs, the secondary lesion score and the paw volume. ${ }^{18}$ The determination of the number of leukocytes recruited in the femorotibial joint cavities of the legs (injected and not injected) of the arthritic rats was done on day 18 after the induction of arthritis. Evaluation of the secondary lesions scores (in the ears, front legs and tail) was started at the $11^{\text {th }}$ day and repeated daily until the end of the experiment on day 18. The severity of the injury was graded from zero to 5 , zero indicating no injury. The volume of the paw was evaluated in the hind paws of the arthritic rats on days $0,1,3,5,7,10,12,14,16$ and 18 and was measured with a plethysmograph (Ugo Basile $\AA$ ). The results of the paw 
volume were expressed as absolute increases in paw volume $(\mu \mathrm{L})$ relative to the initial volume.

\section{Statistical analysis}

The parameters presented in the graphs and tables are means \pm standard errors of the means. Statistical analysis was done using the GraphPad Prism Software (version 5.0). The statistical significance of the data was analyzed by means of one-way ANOVA followed by Student-Newman-Keuls post-hoc testing with the $5 \%$ significance level $(p \leq 0.05)$.

\section{Results}

\section{Liver and brain oxidative stress indicators}

Evaluations of the oxidative stress indicators in the liver and brain, protein carbonyls (panels A and B), ROS levels (panels $\mathrm{C}$ and $\mathrm{D}$ ) and lipid peroxidation (panels $\mathrm{E}$ and F), are summarized in Fig. 1. In the healthy rats, the yerba mate treatment did not affect any of the three evaluated parameters. Adjuvantinduced arthritis, on the other hand, confirming previous reports, clearly increased protein carbonylation, ROS levels and lipid peroxidation in both tissues. ${ }^{10,12}$ Treatment of the arthritic rats with the yerba mate extract diminished the effects of arthritis on the three parameters. In general terms, the effect tended to be more pronounced in the liver than in the brain, and in general, also no differences were found for the actions of the two doses that were employed (400 and $800 \mathrm{mg} \mathrm{kg}^{-1}$ ). In two cases, lipid peroxidation in the liver of the arthritic rats (panel E) and ROS levels in the brain of the arthritic rats (panel D), the yerba mate treatment diminished the influence of arthritis to the point that the small differences in comparison with the corresponding controls were no longer statistically significant. Administration of ibuprofen at the dose of $35 \mathrm{mg} \mathrm{kg}^{-1}$ was equally effective on all parameters tested in both tissues.

\section{Plasma oxidative stress and inflammatory indicators}

Fig. 2 illustrates the influence of arthritis and the subsequent yerba mate treatment on oxidative stress and inflammatory indicators in the plasma. None of the four parameters that were investigated, namely protein carbonylation (panel A), antioxidant capacity (FRAP, panel B), myeloperoxidase activity (panel C) and protein thiol levels (panel D), were modified by the yerba mate treatment in the healthy rats. Protein carbonylation (panel A) was increased by arthritis, confirming a previous report. ${ }^{18}$ Both doses of yerba mate diminished the levels of carbonylated proteins, but to values that were still clearly above those in the healthy rats. The action of ibuprofen was also significant, but not very pronounced. The ferric ion reducing ability (FRAP; panel $\mathrm{B}$ ), an indicator of the antioxidant capacity, was diminished by arthritis, again confirming previous reports. ${ }^{18}$ The yerba mate treatment attenuated the influence of arthritis, the $800 \mathrm{mg} \mathrm{kg}^{-1}$ dose tending to be more effective than the $400 \mathrm{mg} \mathrm{kg}^{-1}$ dose. A similar effect was found in the ibuprofen treated arthritic rats. The marked influ- ence of arthritis on the myeloperoxidase activity (MPO; panel C), a 4.5-fold increase, also confirms previous reports. ${ }^{18}$ Treatment with yerba mate caused diminutions in the increased MPO activities, the $400 \mathrm{mg} \mathrm{kg}^{-1}$ dose being less effective than the $800 \mathrm{mg} \mathrm{kg}{ }^{-1}$ dose. However, even under treatment with the highest dose, the arthritic rats still presented MPO levels 2.9 times above those in the healthy rats. The effect of ibuprofen treatment was similar to that of the $800 \mathrm{mg} \mathrm{kg}^{-1}$ dose of yerba mate. Panel D, finally, also confirms the action of arthritis on the protein thiol levels in the plasma, which consists in a pronounced diminution. ${ }^{18}$ Here, the action of the yerba mate treatment was clearly effective, with a clear tendency toward normalization, at least in terms of statistical significance. Both doses, however, had the same effect, which was similar to that of the ibuprofen treatment.

Another set of observations concerning plasma indicators for arthritis and the response to the yerba mate treatment are listed in Table 2. Yerba mate treatment of healthy rats did not affect any of the parameters listed in Table 2, albumin, globulin and total protein levels and the AST and ALT activities. The decreased albumin level in the arthritic rats confirms a previous observation, the same being true for the increased globulin level. ${ }^{10}$ The yerba mate treatment preserved partially the normal levels of both albumin and globulins, the same applying evidently to the albumin/globulin ratio. Both doses, 400 and $800 \mathrm{mg} \mathrm{kg}^{-1}$, acted similarly. The ibuprofen treatment was equally effective. There was also a strong tendency toward higher AST levels in the arthritic rats, a phenomenon that presents considerable variations among different studies. ${ }^{10,30}$ In principle, the tendency is for a normalization by the yerba mate treatment and by the ibuprofen treatment.

\section{Brain and liver GSH and GSSG contents}

The important components of the cellular oxidative homeostasis, GSH and GSSG, were investigated in both the liver and brain, and the results are shown in Fig. 3. In addition to the tissue contents of both GSH and GSSG, the GSH/GSSG ratio for each tissue is also shown taking into account its importance as an indicator of the oxidative status. Treatment of healthy rats with $800 \mathrm{mg} \mathrm{kg}^{-1}$ yerba mate extract increased the GSH content in the liver ( panel A). Associated with a small tendency toward smaller levels of GSSG (panel C), a relatively pronounced increase in the GSH/GSSG ratio (panel E) caused by both treatments was found in the liver (63\% for the $400 \mathrm{mg}$ $\mathrm{kg}^{-1}$ dose and $73 \%$ for the $800 \mathrm{mg} \mathrm{kg}^{-1}$ dose). There was also a tendency in this direction in the brain, however, without statistical significance (panel F). Corroborating previous observations, arthritis decreased the GSH levels and raised the GSSG levels in both the liver and brain leading to a pronounced decrease in the GSH/GSSG ratios in both tissues. ${ }^{10,12}$ In the liver, the treatment with both doses of yerba mate almost totally prevented these changes (panels A, C, E). The ibuprofen treatment was almost equally effective in this respect. In the brain, the yerba mate had similar effects, but the lower dose (400 $\mathrm{mg} \mathrm{kg}^{-1}$ ) tended to be less effective than the higher one $\left(800 \mathrm{mg} \mathrm{kg}^{-1}\right)$. Remarkably, in the brain, the 

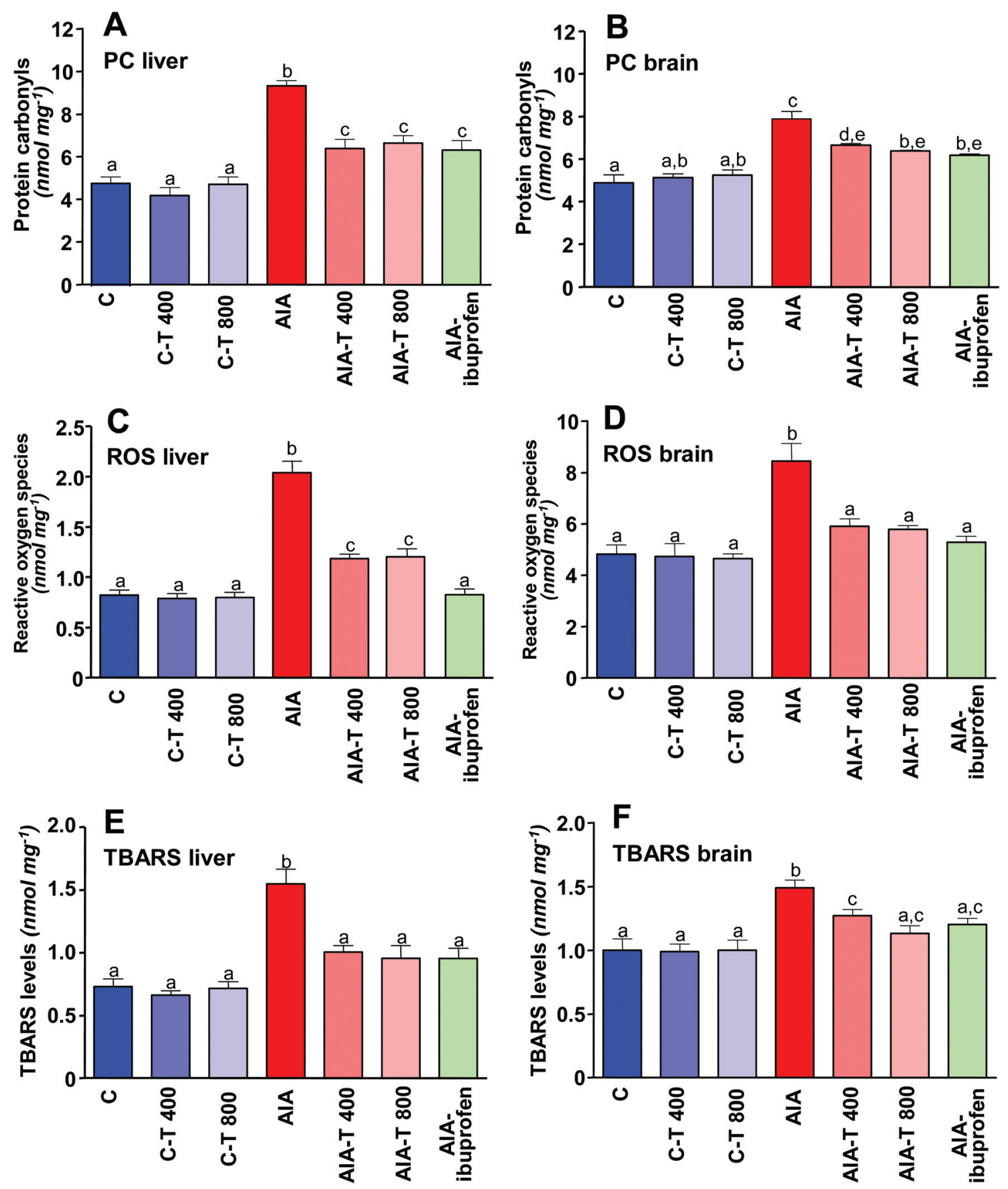

Fig. 1 Effects of the aqueous extract of yerba mate treatment on oxidative stress indicators in the liver and brain. Legends: C, controls; C-T 400, controls treated with $400 \mathrm{mg} \mathrm{kg}^{-1}$ yerba mate extract; C-T 800, controls treated with $800 \mathrm{mg} \mathrm{kg}^{-1}$; AlA, adjuvant-induced arthritic rats; AlA-T 400, arthritic rats treated with $400 \mathrm{mg} \mathrm{kg}^{-1}$; AIA-T 800 , arthritic rats treated with $800 \mathrm{mg} \mathrm{kg}^{-1}$; AIA-ibuprofen, arthritic rats treated with $35 \mathrm{mg} \mathrm{kg}{ }^{-1}$ ibuprofen. The data represent the mean \pm SEM of 6 (healthy) or 7 (arthritic) rats. Columns with the same letters do not differ statistically from each other ( $p \leq 0.05$ ) according to one-way ANOVA followed by Student-Newman-Keuls post hoc testing.

ibuprofen treatment was poorly effective in preventing the decrease in the GSH/GSSG ratio (panel F).

\section{Brain and liver enzyme activities linked to the oxidative state}

The effects of arthritis and the yerba mate treatment on the activities of the enzymes involved in the interconversion of
GSH/GSSG are shown in Fig. 4. In the healthy rats, yerba mate had no significant effects on either glutathione reductase (panels A and B) or glutathione peroxidase activities (panels C and D) in both tissues, liver and brain. Arthritis, however, diminished the activities of both enzymes in the liver and brain, confirming previous observations. ${ }^{10,12}$ Treatment with 

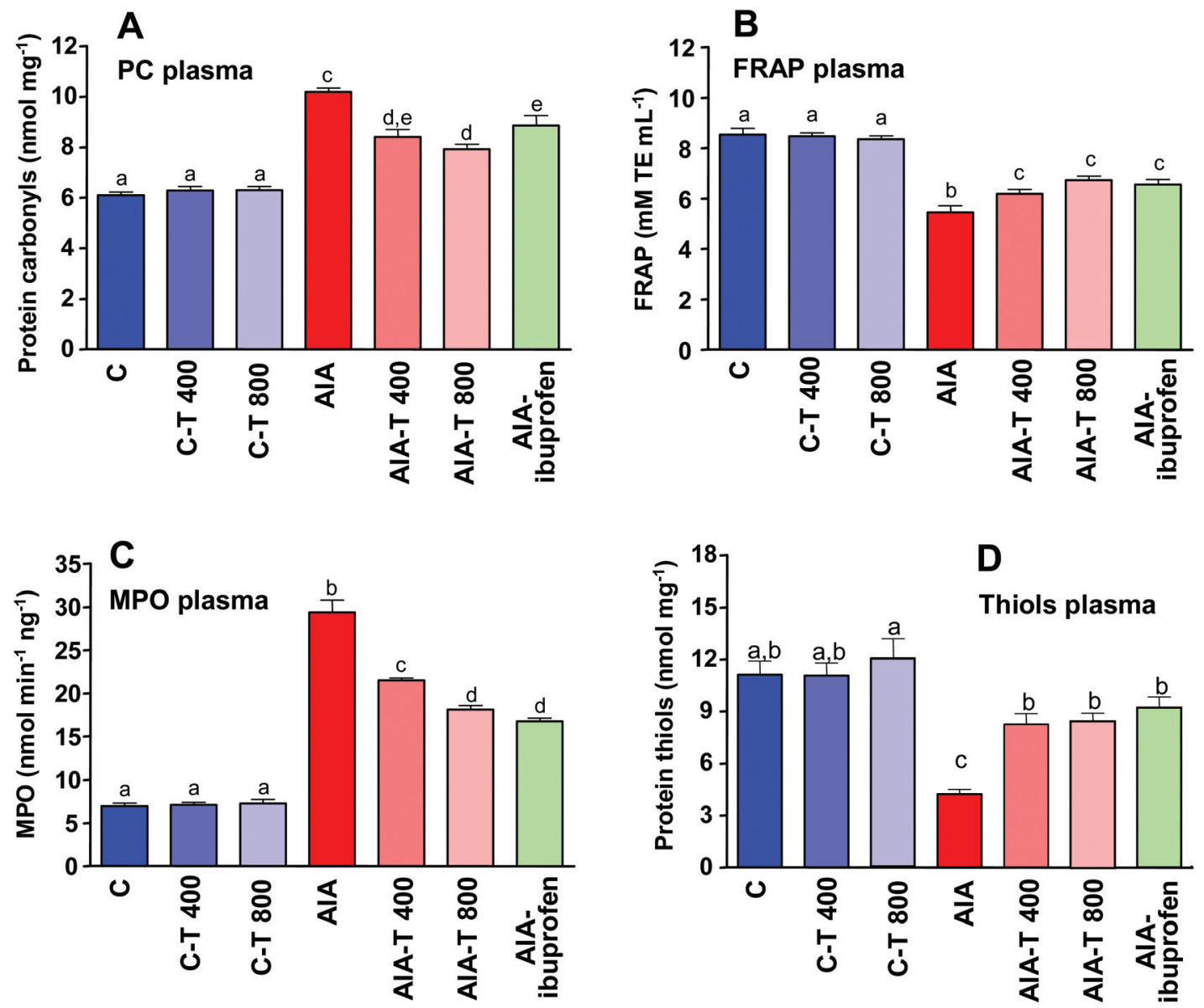

Fig. 2 Effects of the aqueous extract of yerba mate treatment on oxidative stress and inflammation indicators in plasma. Legends: $\mathrm{C}$, controls; $\mathrm{C}$ - $\mathrm{T}$ 400 , controls treated with $400 \mathrm{mg} \mathrm{kg}^{-1}$ yerba mate extract; C-T 800, controls treated with $800 \mathrm{mg} \mathrm{kg}^{-1}$; AlA, adjuvant-induced arthritic rats; AlA-T 400 , arthritic rats treated with $400 \mathrm{mg} \mathrm{kg}^{-1}$; AIA-T 800, arthritic rats treated with $800 \mathrm{mg} \mathrm{kg}^{-1}$; AlA-ibuprofen, arthritic rats treated with 35 mg kg ibuprofen. The data represent the mean \pm SEM of 6 (healthy) or 7 (arthritic) rats. Columns with the same letters do not differ statistically from each other $(p \leq 0.05)$ according to one-way ANOVA followed by Student-Newman-Keuls post hoc testing.

yerba mate extracts almost totally prevented the decrease in the glutathione reductase activities in both the liver and brain (panels A and B). Both doses were equally efficient. Ibuprofen treatment had the same effect. In the brain, the yerba mate and ibuprofen treatments also prevented the decrease in the glutathione peroxidase activity (panel D). In the liver, however, no such prevention was found, the small tendency toward normality lacking statistical significance for both yerba mate and ibuprofen (panel C).

The activities of three more enzymes, important for the oxidative status of the liver and brain, namely catalase, superoxide dismutase and xanthine oxidase, are shown in Fig. 5. The activities of none of these enzymes were affected by the yerba mate treatment of the healthy rats. The very pronounced decrease in the hepatic catalase activity caused by arthritis was not prevented at all by either yerba mate or ibuprofen administration (panel A).$^{10}$ The much smaller decrease in the brain, ${ }^{12}$ however, was prevented by the yerba mate treatment, but not by the ibuprofen treatment (panel B). The diminutions of the superoxide dismutase activities of the liver and brain caused by arthritis (panels $\mathrm{C}$ and $\mathrm{D}$ ) were prevented at least by the higher yerba mate dose $\left(800 \mathrm{mg} \mathrm{kg}^{-1}\right)$, an action that was shared by the ibuprofen treatment (panels C and D). Xanthine oxidase, finally, was increased by arthritis in both tissues (panels $\mathrm{E}$ and $\mathrm{F}$ ), confirming previous knowledge at least for the brain. ${ }^{12}$ Treatment with the yerba mate extracts prevented these modifications, the effect being somewhat more pronounced in the liver. Both doses were equally effective in each tissue. Ibuprofen also prevented the full increase in the activity of xanthine oxidase in both tissues.

\section{Inflammatory indicators}

Three inflammatory indicators, usually prominent in the adjuvant-induced arthritic rat, were investigated for the influence of the yerba mate treatment: (a) paw edema, (b) secondary lesions and (c) number of leukocytes recruited in the femorotibial joint cavities. Fig. 6A and B show the time courses of the increases in paw volume, a direct indication of the inflammatory response that follows Freund's adjuvant injection. As 


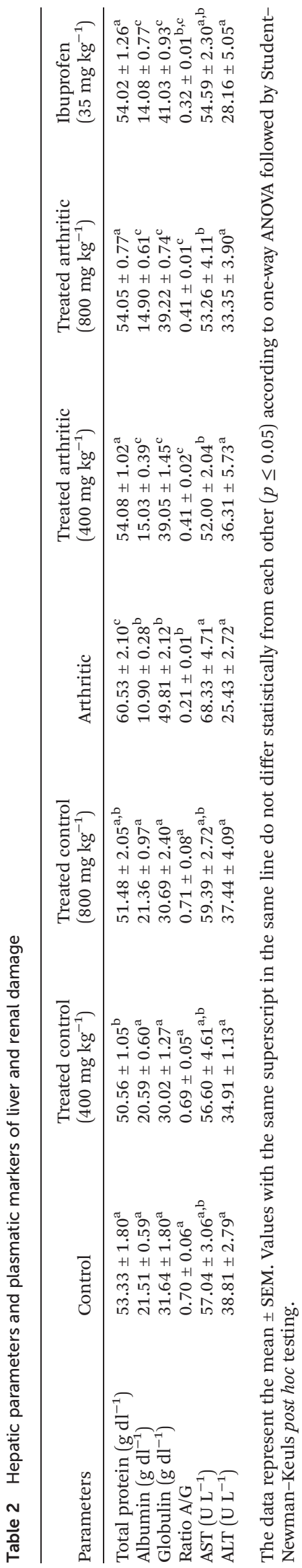

expected, the injected paw responded faster (panel A) than the non-injected paw (panel B). ${ }^{18}$ Treatment with the yerba mate extract or ibuprofen of rats not injected with Freund's adjuvant had no influence on the paw volumes of the rats. Treatment with yerba mate extracts or ibuprofen of rats injected with the Freund's adjuvant, on the other hand, had a diminishing effect on the development of the edema.

Fig. 6C shows the evaluation of the secondary lesion score in the ears, front legs and tail, according to the standardized protocol described in the Materials and methods section. The severity of the injury was graded from zero to 5 , with zero indicating no injury. All treatments, lower and higher doses of yerba mate extract and ibuprofen, delayed the appearance of the secondary lesions equally. The difference between the treated and non-treated rats, however, diminished continuously in the period between days 11 and 17 .

Data on the recruitment of leukocytes into the femorotibial joint cavities in consequence of arthritis are shown in Table 3. Confirming previous observations, the numbers of both mononuclear and polymorphonuclear leukocytes in the right and left knees were enormously increased by arthritis. ${ }^{18}$ The treatment of the arthritic rats with the yerba mate extract caused further increases in the number of mononuclear leukocytes in both the left and right femorotibial joint cavities. This effect was not observed upon the ibuprofen treatment. The number of polymorphonuclear leukocytes, on the other hand, was diminished by the treatment with the yerba mate extract. This effect was dose-dependent, the higher dose being more effective. The ibuprofen treatment, however, in which the $35 \mathrm{mg}$ $\mathrm{kg}^{-1}$ dose was used, was considerably more efficient in reducing the number of infiltrated polymorphonuclear leukocytes.

\section{Discussion}

The experimental model used in this study is characterized by a widespread inflammatory response. It can, thus, be considered a severe arthritis model in rats. ${ }^{9}$ The general outcome of this study can be summarized as a positive demonstration that the yerba mate extract used in this study can diminish both the oxidative stress induced by adjuvant-induced arthritis and several of the inflammatory events that characterize the disease. We used two doses of the yerba mate extract, 400 and $800 \mathrm{mg} \mathrm{kg}^{-1}$, which correspond to the polyphenolics doses listed in Table 1 . In terms of chlorogenic acids this corresponds to daily doses of 14.29 and $28.57 \mathrm{mg} \mathrm{kg}^{-1}$, respectively. It has been estimated that consumers of the traditional beverage chimarrão may ingest daily up to $1 \mathrm{~g}$ of chlorogenic acids. ${ }^{31}$ For an individual weighing $75 \mathrm{~kg}$, this would correspond to a dose of $13.4 \mathrm{mg} \mathrm{kg} \mathrm{kg}^{-1}$. The smaller dose of extract given to the rats in our experiments is, thus, close to the yerba mate ingestion by consumers of the traditional beverage chimarrão. This is a dose for which no significant toxicological manifestations have ever been communicated, a fact that was corroborated, among others, by data of a previous investigation of our group. ${ }^{5}$ 

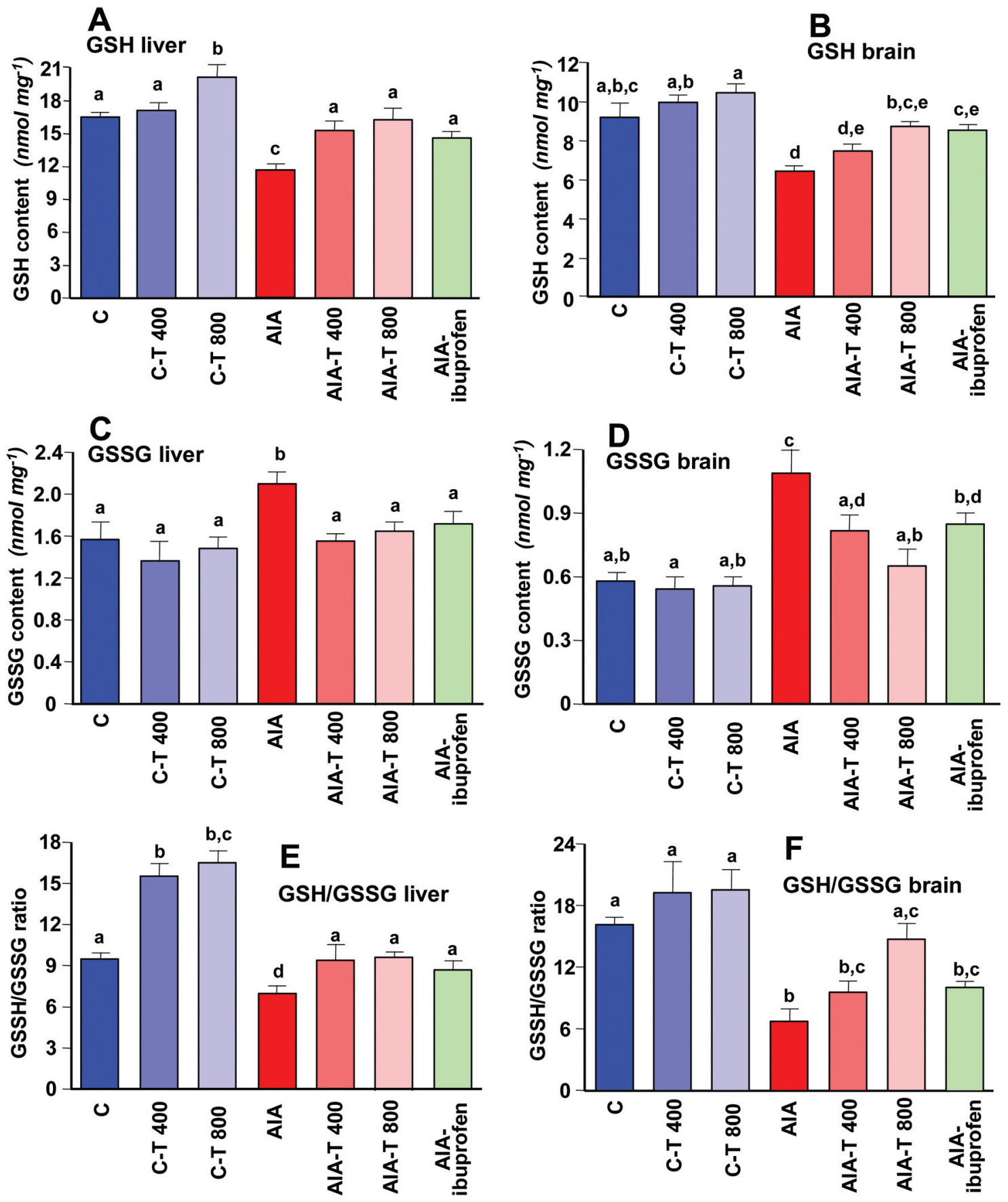

Fig. 3 Effects of the aqueous extract of yerba mate treatment on GSH and GSSG levels in the liver and brain. Legends: C, controls; C-T 400, controls treated with $400 \mathrm{mg} \mathrm{kg}^{-1}$ yerba mate extract; C-T 800, controls treated with $800 \mathrm{mg} \mathrm{kg}^{-1}$; AIA, adjuvant-induced arthritic rats; AIA-T 400, arthritic rats treated with $400 \mathrm{mg} \mathrm{kg}^{-1}$; AIA-T 800, arthritic rats treated with $800 \mathrm{mg} \mathrm{kg}^{-1}$; AIA-ibuprofen, arthritic rats treated with 35 mg kg ${ }^{-1}$ ibuprofen. The data represent the mean \pm SEM of 6 (healthy) or 7 (arthritic) rats. Columns with the same letters do not differ statistically from each other ( $p \leq 0.05$ ) according to one-way ANOVA followed by Student-Newman-Keuls post hoc testing.

The yerba mate extract showed at least some degree of action on most indicators of oxidative stress caused by adjuvant-induced arthritis that were monitored in the present study: (a) it diminished the ROS levels in the liver and brain; (b) it decreased the oxidative protein and lipid damage in the liver and brain; (c) it increased the antioxidant capacity in the plasma as indicated by the FRAP assay, the thiol levels and the albumin levels; (d) it increased the GSH levels and the GSH/ GSSH ratio in both the liver and brain; (e) it almost restored the activities of both enzymes directly linked to the metabolism of GSH-GSSH, glutathione reductase and glutathione peroxidase, in the brain; (f) it almost restored the activity of 

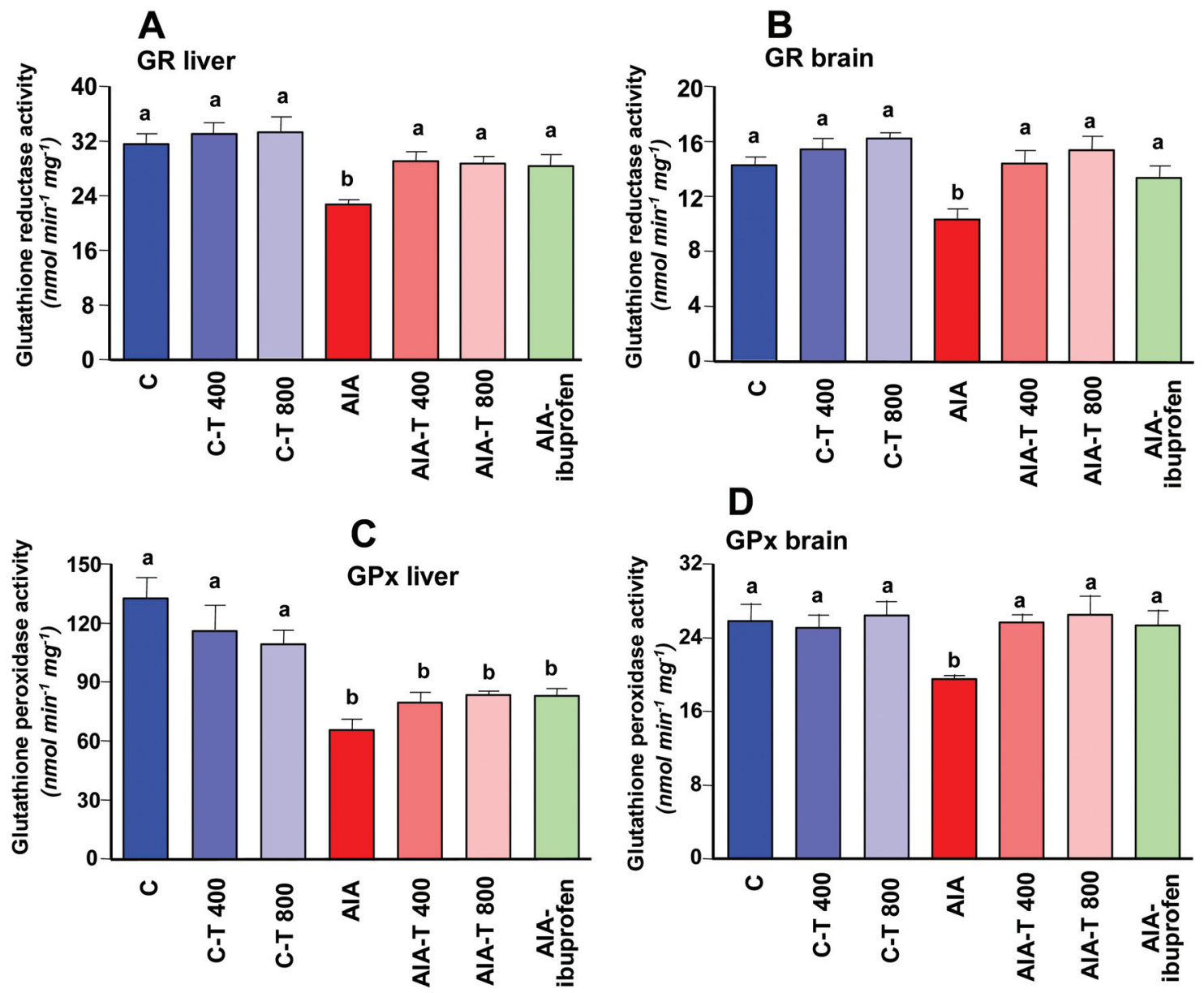

Fig. 4 Effects of the aqueous extract of yerba mate treatment on enzyme activities linked to GSH/GSSG metabolism in the liver and brain. Legends: C, controls; C-T 400, controls treated with $400 \mathrm{mg} \mathrm{kg}^{-1}$ yerba mate extract; C-T 800, controls treated with $800 \mathrm{mg} \mathrm{kg}^{-1}$; AIA, adjuvant-induced arthritic rats; AIA-T 400, arthritic rats treated with $400 \mathrm{mg} \mathrm{kg}^{-1}$; AIA-T 800, arthritic rats treated with $800 \mathrm{mg} \mathrm{kg}^{-1}$; AlA-ibuprofen, arthritic rats treated with $35 \mathrm{mg} \mathrm{kg}^{-1}$ ibuprofen. The data represent the mean \pm SEM of 6 (healthy) or 7 (arthritic) rats. Columns with the same letters do not differ statistically from each other $(p \leq 0.05)$ according to one-way ANOVA followed by Student-Newman-Keuls post hoc testing.

glutathione reductase in the liver, but failed in doing the same with glutathione peroxidase; $(g)$ it also reversed the modified activities of xanthine oxidase and superoxide dismutase in both the liver and brain, whereas a similar action on catalase was found only in the brain. Remarkably, however, the wellknown anti-inflammatory agent ibuprofen $\left(35 \mathrm{mg} \mathrm{kg}^{-1}\right)$, whose action was monitored in parallel experiments, exerted similar effects on most variables measured. The exceptions can be named in short: contrary to the yerba mate extract, ibuprofen did not normalize the CAT activity in the brain of the arthritic rats nor did it restore the SOD activity in the same tissue. Conversely, with respect to the most typical indicators of inflammation, which one expects to be attenuated by ibuprofen, the yerba mate extract had a similar action, although somewhat less pronounced in some cases. The actions of both doses of the yerba mate extract ( 400 and $800 \mathrm{mg} \mathrm{kg}^{-1}$ ) and ibuprofen on the edematous paw volume increases cannot be distinguished from each other, the same being valid for the delay in the development of the secondary lesions resulting from arthritis. The diminution of the highly augmented levels of the plasma myeloperoxidase activity caused by ibuprofen was also not significantly different from the decrease caused by the highest yerba mate dose. Only in the case of the polymorphonuclear leucocytes infiltrations in the femorotibial joint cavities was there a difference between the action of the highest yerba mate dose and ibuprofen, the latter being more effective. The decrease caused by yerba mate in the number of leukocytes recruited into the inflammatory site was already suggested for several inflammation models based on the diminution of the local myeloperoxidase activity. ${ }^{14,15}$

Ilex paraguariensis extracts have been reported to scavenge very effectively DPPH, ABTS, peroxyl radicals and ROS generated by isolated mitochondria and to reduce products formed during lipid peroxidation. ${ }^{5}$ Ibuprofen, however, is basically a non-steroidal anti-inflammatory, whose direct antioxidant action has been reported to be very weak. As other non-steroidal anti-inflammatories, ibuprofen has been found to act as a free-radical scavenger at concentrations around or well above 

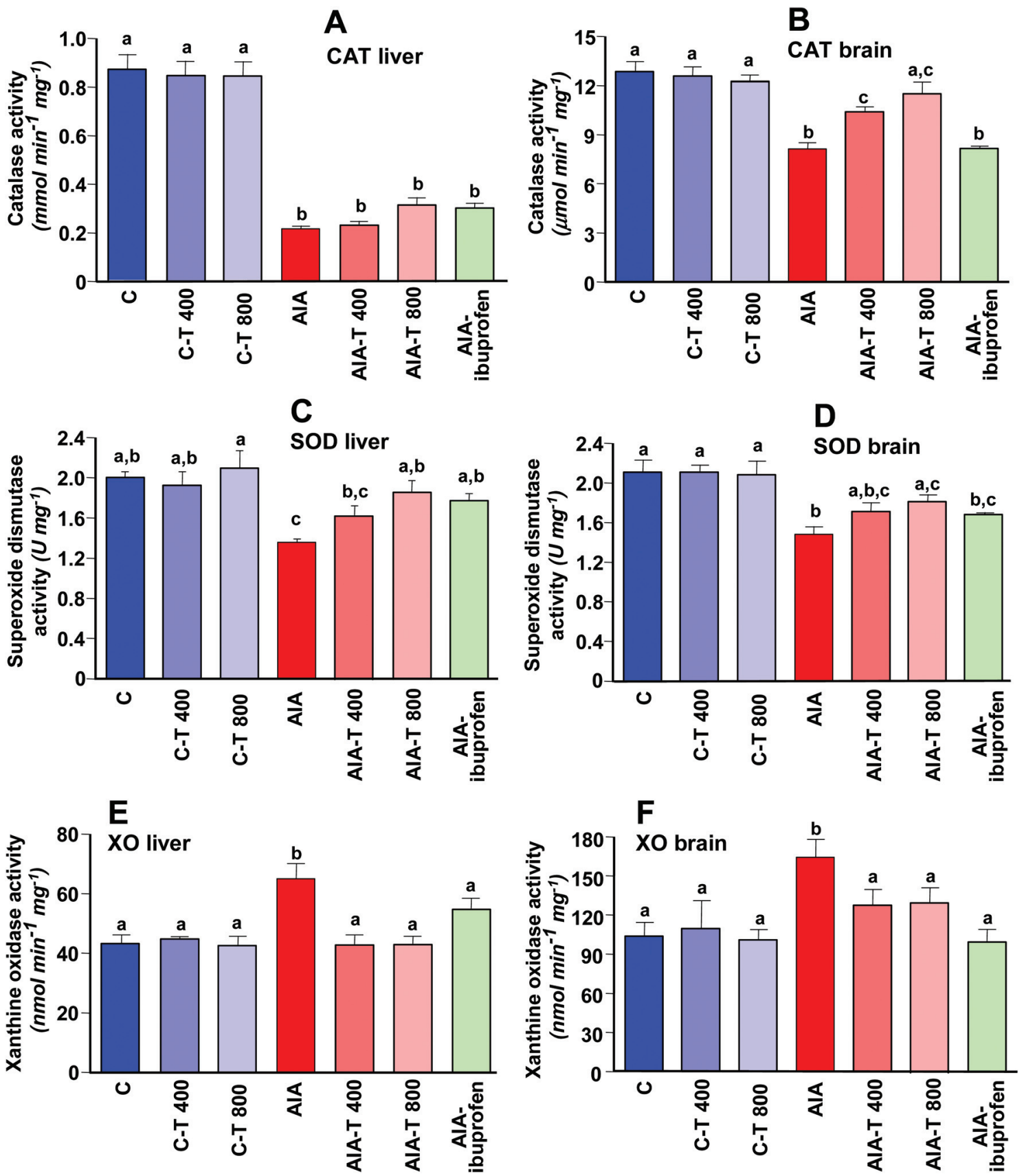

Fig. 5 Effects of the aqueous extract of yerba mate treatment on enzyme activities linked to the oxidative status of the liver and brain. Legends: $\mathrm{C}$, controls; C-T 400, controls treated with $400 \mathrm{mg} \mathrm{kg}^{-1}$ yerba mate extract; C-T 800, controls treated with 800 mg kg ${ }^{-1}$; AIA, adjuvant-induced arthritic rats; AIA-T 400, arthritic rats treated with $400 \mathrm{mg} \mathrm{kg}^{-1}$; AIA-T 800, arthritic rats treated with $800 \mathrm{mg} \mathrm{kg}^{-1}$; AlA-ibuprofen, arthritic rats treated with $35 \mathrm{mg} \mathrm{kg}^{-1}$ ibuprofen. The data represent the mean \pm SEM of 6 (healthy) or 7 (arthritic) rats. Columns with the same letters do not differ statistically from each other $(p \leq 0.05)$ according to one-way ANOVA followed by Student-Newman-Keuls post hoc testing.

$1 \mathrm{mM}$, which can be considered highly improbable for in vivo conditions. $^{32,33}$ For this reason, its effects against oxidative stress in vivo or in isolated cell systems are most probably resulting from its anti-inflammatory action. Consequently, the similar actions listed in the preceding paragraph for the yerba mate extract and ibuprofen on the symptoms of arthritis raise the question if, after all, the main action of the yerba mate extract is much more linked to its anti-inflammatory action than to its antioxidant activity. Actually, anti-inflammatory activity in several experimental models has been frequently demonstrated for several components of yerba mate. The group of compounds sometimes referred collectively as caffeic acid derivatives (salvianolic acid I and chlorogenic acids, especially 3-O-caffeoylquinic, 4-O-caffeoylquinic, 5-O-caffeoylquinic, 3,5-O-dicaffeoylquinic acids, etc.), for example, are quite abundant in yerba mate (see Table 1$).{ }^{5}$ It should be men- 

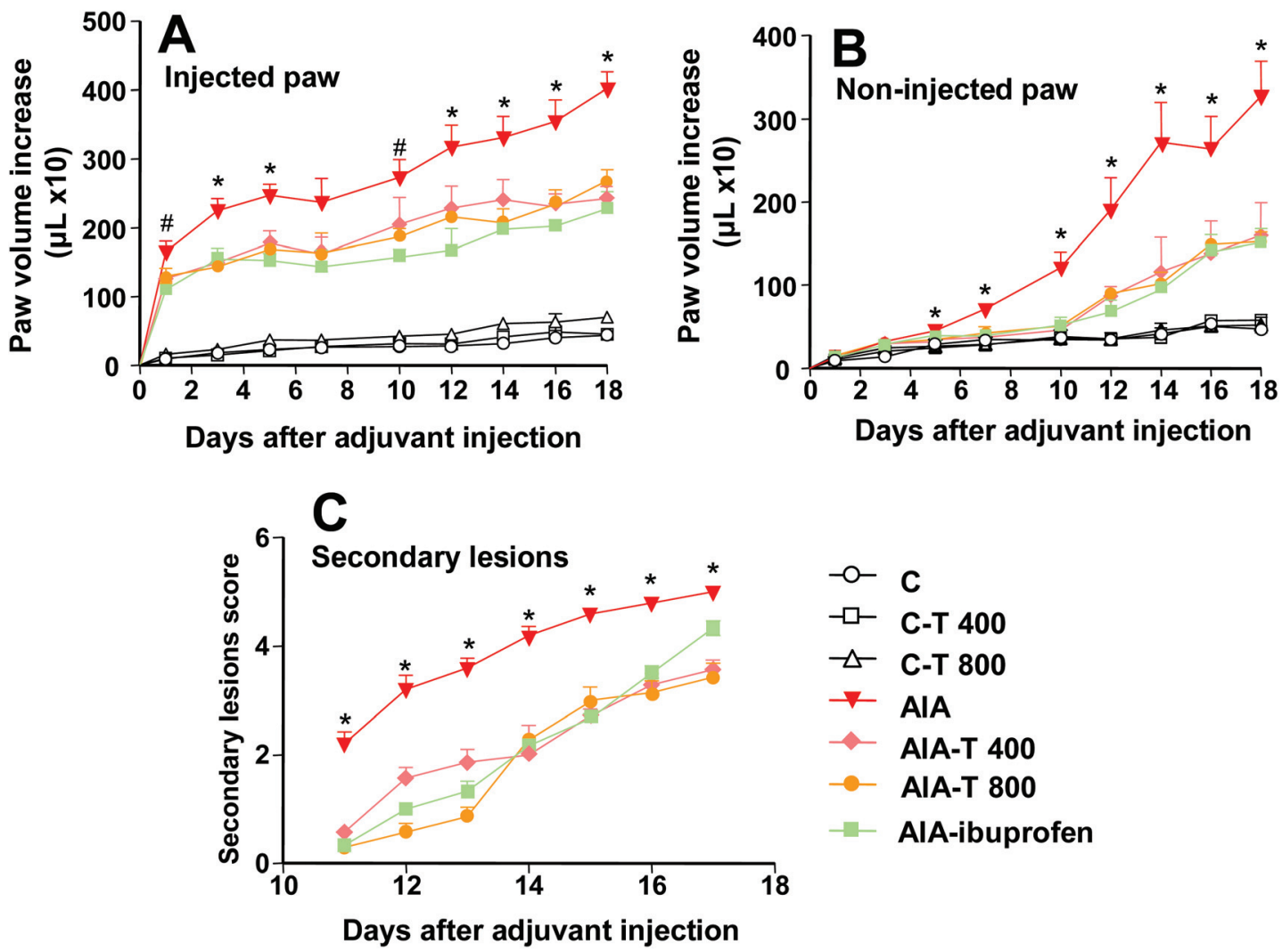

Fig. 6 Influence of the aqueous extract of yerba mate treatment on the development of the inflammatory response to the Freund's adjuvant injection. Legends: C, controls; C-T 400, controls treated with $400 \mathrm{mg} \mathrm{kg}^{-1}$ yerba mate extract; C-T 800, controls treated with 800 mg kg ${ }^{-1}$; AlA, adjuvant-induced arthritic rats; AIA-T 400, arthritic rats treated with $400 \mathrm{mg} \mathrm{kg}^{-1}$; AIA-T 800, arthritic rats treated with 800 mg kg ${ }^{-1}$; AIA-ibuprofen, arthritic rats treated with $35 \mathrm{mg} \mathrm{kg}^{-1}$ ibuprofen. The data represent the mean \pm SEM of 6 (healthy) or 7 (arthritic) rats. Asterisks (*) indicate significant differences between the AIA group and all others $(p \leq 0.05)$, and dashes $(\#)$ indicate significant differences between the AIA group and AIA-ibuprofen group according to one-way ANOVA followed by Student-Newman-Keuls post hoc testing.

tioned, however, that all these compounds are rapidly transformed in vivo. It has been shown, for example, that hydrolysis of chlorogenic acids by esterases occurs rapidly after oral administration to both rats and humans so that the peak plasma concentrations of these compounds are considerably lower than the peak plasma concentrations of their transformation products. ${ }^{6,7}$ The latter are mainly caffeic and ferulic acids. For these compounds, however, anti-oxidant activities have also been demonstrated, so that it is likely that a considerable part of the antioxidant action observed in the present work is actually exerted by metabolites of the chlorogenic acids rather than by the parent compounds themselves. ${ }^{34-36}$ Besides their antioxidant actions, both chlorogenic acids and their metabolites also exert anti-inflammatory activity as demonstrated in several models, including rheumatoid arthritis. ${ }^{34-37}$ It was found, for example, that oral administration of $40 \mathrm{mg} \mathrm{kg}^{-1}$ of 5-O-caffeoylquinic acid (chlorogenic acid) effectively suppressed the pro-inflammatory cytokines TNF $\alpha$ and IL-1 $\beta$ in a lipopolysaccharide-induced arthritis model in rats. ${ }^{38}$ In line with our findings is the observation that a similar treatment with ibuprofen produced similar effects. Furthermore, I. paraguariensis extracts inhibit the activity of pro-inflammatory enzymes such as cyclooxygenase-2 and the inducible nitric oxide synthase. ${ }^{15}$ These effects have also been demonstrated for pure chlorogenic acid. ${ }^{39}$ Moreover, treatment with yerba mate decreases the levels of adenosine deaminase (ADA), which, in turn, could mean a diminution of neutrophil degranulation and its oxidant activity. ${ }^{14}$ The decrease in neutrophil activation may also be related to plasma myeloperoxidase levels, considering that the enzyme is present in the azurophilic granules of neutrophils and released when these cells are activated. ${ }^{14}$

All these observations mentioned in the preceding paragraph and several others to be found in the literature confirm, thus, the importance of the anti-inflammatory actions of yerba mate, mediated by salvianolic acid I (a caffeic acid trimer), chlorogenic acids (especially 3-O-caffeoylquinic, 4-O-caffeoylquinic, 5-O-caffeoylquinic and 3,5-O-dicaffeoylquinic acids) and probably by their metabolites caffeic and ferulic acids, which could be largely responsible also for its anti-oxidant action. Analysis of the total administered amount of these compounds, displayed in Table 1 , reveals that they are within the same range as the dose of ibuprofen that was administered and that produced similar effects. On the other hand, direct 
Table 3 Effects of the yerba mate extract and ibuprofen treatments on the mononuclear and polymorphonuclear leukocyte counts in the right and left femorotibial joint cavities of the adjuvant-induced arthritic rats. The data represent the mean $\pm \mathrm{SEM}$. Values labeled in the same column with the same letter do not differ statistically from each other $(p<0.05)$ according to one-way ANOVA followed by Student-Newman-Keuls post hoc testing

\begin{tabular}{|c|c|c|c|c|}
\hline \multirow[b]{2}{*}{ Groups } & \multicolumn{2}{|c|}{ Right femorotibial joint cavity } & \multicolumn{2}{|c|}{ Left femorotibial joint cavity } \\
\hline & $\begin{array}{l}\text { Mononuclear } \\
\text { leukocytes }\end{array}$ & $\begin{array}{l}\text { Polymorphonuclear } \\
\text { leukocytes }\end{array}$ & $\begin{array}{l}\text { Mononuclear } \\
\text { leukocytes }\end{array}$ & $\begin{array}{l}\text { Polymorphonuclear } \\
\text { leukocytes }\end{array}$ \\
\hline Control & $2.43 \pm 0.05^{\mathrm{a}}$ & $0.57 \pm 0.05^{\mathrm{a}}$ & $2.08 \pm 0.03^{\mathrm{a}}$ & $0.48 \pm 0.03^{\mathrm{a}}$ \\
\hline Arthritic & $58.82 \pm 3.36^{\mathrm{b}}$ & $173.15 \pm 3.89^{\mathrm{b}}$ & $86.41 \pm 4.35^{\mathrm{b}}$ & $334.79 \pm 8.49^{\mathrm{b}}$ \\
\hline Treated arthritic (400 $\mathrm{mg} \mathrm{kg}^{-1}$ ) & $77.68 \pm 3.81^{c}$ & $110.52 \pm 2.68^{c}$ & $123.13 \pm 4.98^{c}$ & $197.51 \pm 2.72^{\mathrm{c}}$ \\
\hline Treated arthritic $\left(800 \mathrm{mg} \mathrm{kg}^{-1}\right)$ & $75.69 \pm 2.74^{\mathrm{c}}$ & $72.57 \pm 1.82^{\mathrm{d}}$ & $106.23 \pm 2.91^{\mathrm{d}}$ & $137.74 \pm 4.17^{\mathrm{d}}$ \\
\hline Ibuprofen $\left(35 \mathrm{mg} \mathrm{kg}^{-1}\right)$ & $67.52 \pm 2.62^{b, c}$ & $38.88 \pm 3.01^{\mathrm{e}}$ & $93.17 \pm 2.52^{\mathrm{b}}$ & $61.10 \pm 2.47^{\mathrm{e}}$ \\
\hline
\end{tabular}

free radical scavenging by components of yerba mate is a wellestablished phenomenon ${ }^{4,5}$ and it is likely that this property equally contributed in some way to the overall effect of the extract used in the present work. It is generally accepted that ROS, initially produced in consequence of the inflammatory events, can additionally increase the inflammatory response by effecting NF-kB signaling, modulating proximal events in (TLR)-4 signaling. ${ }^{40}$ Inflammation and ROS production are, thus, interdependent phenomena capable of mutually influencing each other. ROS scavenging by the yerba mate extract compounds, therefore, could be equally active in reducing the inflammatory response. Improvement in inflammation via TLR4/MyD88/NF-кB has indeed been shown to occur in spinal cord injured rats by treatment with chlorogenic acid. ${ }^{38}$

A direct action on the antioxidant defenses by components of the yerba mate extract is also suggested by the effects of the GSH levels and the GSH/GSSG redox ratio. We found in this work that the yerba mate treatment increased both variables in the liver of the healthy rats. Similar observations were also done in healthy humans in which the yerba mate treatment improved the GSH levels and promoted a significant enhancement in the catalase $(28.7 \%)$, superoxide dismutase $(21.3 \%)$, and glutathione peroxidase $(9.6 \%)$ activities. $^{41}$

There is an interesting parallel that can be traced between Ilex paraguariensis (yerba mate) and Camellia sinensis (especially green tea). ${ }^{42}$ Both have been used traditionally for the preparation of stimulant beverages, originally in two different continents, Asia and South America. Camellia sinensis has since long gained an almost universal distribution and acceptance, whereas this process is presently at its beginnings for Ilex paraguariensis. However, to both species effects against several health disorders have been attributed in addition to the stimulating actions exerted by their methylxanthine constituents (caffeine, theobromine and theophylline). The common list includes antidiabetic actions, cancer prevention, antioxidant properties and anti-inflammatory effects. Unsurprisingly, the results obtained in the present study with Ilex paraguariensis are very similar to the results obtained in a previous study of our group with Camellia sinensis (green tea). ${ }^{43}$ The green tea extract improved the oxidative state of the adjuvant-induced arthritic rats by affecting practically the same parameters in the liver, brain and plasma as the yerba mate extract: diminution of ROS contents, diminution of damage to proteins and lipids and increases in the antioxidant defenses. ${ }^{43}$ There are also studies indicating antiinflammatory actions for green tea and green tea components. ${ }^{44,45}$ These and other similarities certainly reinforce the parallelism of both species as medicinal plants worldwide. However, it is equally important to note that their most important bioactive compounds are not the same. In Camellia sinensis catechin and catechin derivatives such as (-)-epigallocatechin-3-gallate (EGCG), epigallocatechin (EGC) and epicatechin-3-gallate (ECG) are considered to be the most important active molecules, ${ }^{44}$ whereas in Ilex paraguariensis the group of compounds frequently referred collectively as caffeic acid derivatives, especially salvianolic acid I (a caffeic acid trimer) and chlorogenic acids (mainly 3-O-caffeoylquinic, 4-O-caffeoylquinic, 5-O-caffeoylquinic, and 3,5-O-caffeoylquinic acids (see Table 1)) are likely to be responsible for a significant part of the effects.

\section{Conclusion}

In conclusion, yerba mate administration was beneficial to the adjuvant-induced arthritic rats by diminishing both inflammation and oxidative stress. The latter means also a substantial reduction in the injury to lipids and proteins caused by the disease. It is possible that the anti-inflammatory actions of yerba mate constituents are the primary events producing those beneficial effects. Direct ROS scavenging, however, may also play a significant role since inflammation and ROS production are interdependent phenomena capable of mutually influencing each other. In principle, the same can be expected for patients suffering from rheumatoid arthritis if one takes into account the similarities between the latter pathological manifestation and the adjuvant-induced disease in rats. One can also expect that the continued daily ingestion of the traditional yerba mate beverages (e.g., in the form of chimarrão in Brazil), a common practice of millions of people in the southern cone of South America, may be effective in attenuating the symptoms of inflammatory diseases, especially in older adults. 


\section{Conflicts of interest}

There are no conflicts to declare.

\section{Acknowledgements}

This work was financially supported by grants from the Conselho Nacional de Desenvolvimento Científico e Tecnológico (CNPq-307944/2015-8), Coordenação do Aperfeiçoa-mento de Pessoal do Ensino Superior (CAPES) and Fundação Araucária. The authors are also indebted to Jailson Araújo Dantas for his technical assistance and to Dr Ciomar A. B. Amado for facilitating access to equipment of the Pharmacology and Therapeutics Department of the State University of Maringá. The authors are also grateful to the Foundation for Science and Technology (FCT, Portugal) and FEDER under Programme PT2020 for financial support to CIMO (UID/AGR/00690/2013) and L. Barros contract.

\section{References}

1 N. Bracesco, A. G. Sanchez, V. Contreras, T. Menini and A. Gugliucci, Recent advances on Ilex paraguariensis research: Minireview, J. Ethnopharmacol., 2011, 136(3), 378384, DOI: 10.1016/j.jep.2010.06.032.

2 C. I. Heck and E. G. de Mejia, Yerba mate tea (Ilex paraguariensis): a comprehensive review on chemistry, health implications, and technological considerations, J. Food Sci., 2007, 72(9), R138-R151, DOI: 10.1111/j.1750-3841.2007.00535.x.

3 V. G. Correa, R. C. G. Correa, T. F. Vieira, E. A. Koehnlein, A. Bracht and R. M. Peralta, Yerba mate (Ilex paraguariensis A. St. Hil): a promising adjuvant in the treatment of diabetes, obesity, and metabolic syndrome, in Nutraceuticals and Natural Product Derivatives: Disease Prevention \& Drug Discovery, ed. M. F. Ullah and A. Ahmad, John Wiley \& Sons, Hoboken, New Jersey-USA, 2019, pp. 167-181.

4 A. H. P. Souza, R. C. G. Corrêa, L. Barros, R. C. Calhelha, C. Santos-Buelga, R. M. Peralta, A. Bracht, M. Matsushita and I. C. F. R. Ferreira, Phytochemicals and bioactive properties of Ilex paraguariensis: An in vitro comparative study between the whole plant, leaves and stems, Food Res. Int., 2015, 78, 286-294, DOI: 10.1016/J.FOODRES.2015.09.032.

5 V. G. Correa, G. A. Gonçalves, A. B. de Sá-Nakanishi, I. C. F. R. Ferreira, L. Barros, M. I. Dias, E. A. Kohnlein, C. G. M. de Souza, A. Bracht and R. M. Peralta, Effects of in vitro digestion and in vitro colonic fermentation on stability and functional properties of yerba mate (Ilex paraguariensis A. St. Hil.) beverages, Food Chem., 2017, 237, 453-460, DOI: 10.1016/J.FOODCHEM.2017.05.125.

6 D. M. Oliveira, G. R. Sampaio, C. B. Pinto, R. R. Catharino and D. H. M. Bastos, Bioavailability of chlorogenic acid in rats after acute ingestion of maté tea (Ilex paraguariensis) or 5-caffeoylquinic acid, Eur. J. Nutr., 2017, 56, 2541-2556, DOI: $10.1007 /$ s00394-016-1290-1.
7 A. Stalmach, W. Mullen, D. Barron, K. Uchida, T. Yokota, C. Cavin, H. Steiling, G. Williamson and A. Crozier, Metabolite profiling of hydroxycinnamate derivatives in plasma and urine after the ingestion of coffee by humans: identification of biomarkers of coffee consumption, Drug Metab. Dispos., 2009, 37, 1749-1758, DOI: 10.1124/ dmd.109.028019.

8 M. Stolina, B. Bolon, S. Middleton, D. Dwyer, H. Brown, D. Duryea, L. Zhul, A. Rohner, J. Pretorius, P. Kostenuik, U. Feige and D. Zack, The evolving systemic and local biomarker milieu at different stages of disease progression in rat adjuvant-induced arthritis, J. Clin. Immunol., 2009, 29(2), 158-174, DOI: 10.1007/s10875-008-9238-8.

9 A. Bracht, S. S. Silveira, C. V. Castro-Ghizoni, A. B. SáNakanishi, M. R. N. Oliveira, C. A. Bersani-Amado, R. M. Peralta and J. F. Comar, Oxidative changes in the blood and serum albumin differentiate rats with monoarthritis and polyarthritis, SpringerPlus, 2016, 5(1), 1-14, DOI: 10.1186/s40064-016-1671-1.

10 J. F. Comar, A. Babeto de Sá-Nakanishi, A. L. de Oliveira, M. M. N. Wendt, C. A. Bersani Amado, E. L. Ishii Iwamoto, R. M. Peralta and A. Bracht, Oxidative state of the liver of rats with adjuvant-induced arthritis, Free Radical Biol. Med., 2013, 58, 144-153, DOI: 10.1016/j. freeradbiomed.2012.12.003.

11 A. C. Schubert, M. N. N. Wendt, A. B. de Sá-Nakanishi, C. A. B. Amado, R. M. Peralta, J. F. Comar and A. Bracht, Oxidative state and oxidative metabolism of the heart from rats with adjuvant-induced arthritis, Exp. Mol. Pathol., 2016, 100(3), 393-401, DOI: 10.1016/J.YEXMP.2016.03.005.

12 M. M. N. Wendt, A. B. de Sá-Nakanishi, C. V. de Castro Ghizoni, C. A. B. Amado, R. M. Peralta, A. Bracht and J. F. Comar, Oxidative state and oxidative metabolism in the brain of rats with adjuvant-induced arthritis, Exp. Mol. Pathol., 2015, 98(3), 549-557, DOI: 10.1016/j. yexmp.2015.04.002.

13 M. C. Borges, M. A. R. Vinolo, K. Nakajima, I. A. de Castro, D. H. Bastos, P. Borelli, R. A. Fock, J. Tirapegui, R. Curi and M. M. Rogero, The effect of mate tea Ilex paraguariensis on metabolic and inflammatory parameters in high-fat dietfed Wistar rats, Int. J. Food Sci. Nutr., 2013, 64(5), 561-569, DOI: 10.3109/09637486.2012.759188.

14 A. B. G. Luz, C. H. B. da Silva, M. V. P. S. Nascimento, B. M. de Campos Facchin, B. Baratto, T. S. Fröde, F. H. Reginatto and E. M. Dalmarco, The anti-inflammatory effect of Ilex paraguariensis A. St. Hil (Mate) in a murine model of pleurisy, Int. Immunopharmacol., 2016, 36, 165172, DOI: 10.1016/J.INTIMP.2016.04.027.

15 G. Schinella, E. Neyret, G. Cónsole, H. Tournier, J. Prieto, J. L. Ríos and R. Giner, An aqueous extract of Ilex paraguariensis reduces carrageenan-induced edema and inhibits the expression of cyclooxygenase- 2 and inducible nitric oxide synthase in animal models of inflammation, Planta Med., 2014, 80(12), 961-968, DOI: 10.1055/s-0034-1382876.

16 A. Bendele, J. Mccomb, T. Gould, T. Mcabee, G. Sennello, E. Chlipala and M. Guy, Animal models of arthritis: rele- 
vance to human disease, Toxicol. Pathol., 1999, 27(1), 134142, DOI: 10.1177/019262339902700125.

17 C. M. Pearson and F. D. Wood, Studies of arthritis and other lesions induced in rats by the injection of mycobacterial adjuvant. VII. Pathologic details of the arthritis and spondylitis, Am. J. Pathol., 1963, 42(1), 73-95.

18 G. de A. Gonçalves, A. B. de Sá-Nakanishi, J. F. Comar, L. Bracht, M. I. Dias, L. Barros, R. M. Peralta, I. C. F. R. Ferreira and A. Bracht, Water soluble compounds of Rosmarinus officinalis $\mathrm{L}$. improve the oxidative and inflammatory states of rats with adjuvant-induced arthritis, Food Funct., 2018, 9(4), 2328-2340, DOI: 10.1039/ C7FO01928A.

19 O. H. Lowry, N. J. Rosebrough, A. L. Farr and R. J. Randall, Protein measurement with the Folin phenol reagent, J. Biol. Chem., 1951, 193(1), 265-275.

20 I. R. Siqueira, C. Fochesatto, I. L. da Silva Torres, C. Dalmaz and C. Alexandre Netto, Aging affects oxidative state in hippocampus, hypothalamus and adrenal glands of Wistar rats, Life Sci., 2005, 78(3), 271-278, DOI: 10.1016/ j.lfs.2005.04.044.

21 P. J. Hissin and R. Hilf, A fluorometric method for determination of oxidized and reduced glutathione in tissues, Anal. Biochem., 1976, 74(1), 214-226.

22 H. U. Bergmeyer, Methods of Enzymatic Analysis, Verlag Chemie-Academic Press, Weinheim-London, 1974.

23 S. Marklund and G. Marklund, Involvement of the superoxide anion radical in the autoxidation of pyrogallol and a convenient assay for superoxide dismutase, Eur. J. Biochem., 1974, 47(3), 469-474.

24 A. L. Tappel, Glutathione peroxidase and hydroperoxides, Methods Enzymol., 1978, 52, 506-513.

25 J. Galilea, E. I. Canela and J. Bozal, The course analysis of guanine and hypoxanthine transformation to uric acid by bovine liver guanine aminihydrolase and xanthine oxidase, J. Mol. Catal., 1981, 12(1), 27-36, DOI: 10.1016/0304-5102 (81)80016-8.

26 P. P. Bradley, D. A. Priebat, R. D. Christensen and G. Rothstein, Measurement of cutaneous inflammation: estimation of neutrophil content with an enzyme marker, J. Invest. Dermatol., 1982, 78(3), 206-209.

27 J. A. Buege and S. D. Aust, Microsomal lipid peroxidation, Methods Enzymol., 1978, 52, 302-310, DOI: 10.1016/S00766879(78)52032-6.

28 R. L. Levine, D. Garland, C. N. Oliver, A. Amici, I. Climent, A. G. Lenz, B. W. Ahn, S. Shaltiel and E. R. Stadtman, Determination of carbonyl content in oxidatively modified proteins, Methods Enzymol., 1990, 186, 464-478.

29 I. F. F. Benzie and J. J. Strain, The ferric reducing ability of plasma (frap) as a measure of "antioxidant power": the FRAP assay, Anal. Biochem., 1996, 239(1), 70-76, DOI: 10.1006/abio.1996.0292.

30 A. C. de Souza, G. de A. Goncalves, A. A. Soares, A. de SáNakanishi, A. P. de Santi-Rampazzo, M. R. M. Natali, R. M. Peralta and A. Bracht, Antioxidant action of an aqueous extract of royal sun medicinal mushroom,
Agaricus brasiliensis (agaricomycetes), in rats with adjuvant-induced arthritis, Int. J. Med. Mushrooms, 2018, 20(2), 101-117, DOI: 10.1615/IntJMedMushrooms.2018025309.

31 D. M. Oliveira and D. H. M. Bastos, Biodisponibilidade de ácidos fenólicos, Quim. Nova, 2011, 34, 1051-1056.

32 D. Costa, L. Moutinho, J. L. F. C. Lima and E. Fernandes, Antioxidant activity and inhibition of human neutrophil oxidative burst mediated by arylpropionic acid non-steroidal anti-inflammatory drugs, Biol. Pharm. Bull., 2006, 29(8), 1659-1670.

33 D. Zapolska-Downar, A. Zapolska-Downar, H. Bukowska, H. Gałka and M. Naruszewicz, Ibuprofen protects low density lipoproteins against oxidative modification, Life Sci., 1999, 65(22), 2289-2303.

34 F. M. da Cunha, D. Duma, J. Assreuy, F. C. Buzzi, R. Niero, M. M. Campos and J. B. Calixto, Caffeic acid derivatives: in vitro and in vivo anti-inflammatory properties, Free Radical Res., 2004, 38, 1241-1253, DOI: 10.1080/10715760400016139.

35 C. Magnani, V. L. B. Isaac, M. A. Correa and H. R. N. Salgado, Caffeic acid: a review of its potential use in medications and cosmetics, Anal. Methods, 2014, 6, 3203-3210, DOI: 10.1039/c3ay41807c.

36 H. Zhu, Q. H. Liang, X. G. Xiong, J. Chen, D. Wu, Y. Wang, B. Yang, Y. Zhang, Y. Zhang and X. Huang, Anti-inflammatory effects of the bioactive compound ferulic acid contained in oldenlandia diffusa on collagen-induced arthritis in rats, Evid.-Based Complement. Alternat. Med., 2014, 573801, DOI: 10.1155/2014/573801.

37 N. Liang and D. Kitts, Role of chlorogenic acids in controlling oxidative and inflammatory stress conditions, Nutrients, 2015, 8(1), 16, DOI: 10.3390/nu8010016.

38 P. S. Chauhan, N. K. Satti, P. Sharma, V. K. Sharma, K. A. Suri and S. Bani, Differential effects of chlorogenic acid on various immunological parameters relevant to rheumatoid arthritis, Phytother. Res., 2012, 26(8), 11561165, DOI: 10.1002/ptr.3684.

39 D. Chen, D. Pan, S. Tang, Z. Tan, Y. Zhang, Y. Fu, G. Lü and Q. Huang, Administration of chlorogenic acid alleviates spinal cord injury via TLR4/NF- $\mathrm{BB}$ and p38 signaling pathway anti-inflammatory activity, Mol. Med. Rep., 2017, 17(1), 1340-1346, DOI: 10.3892/mmr.2017.7987.

40 K. Asehnoune, D. Strassheim, S. Mitra, Y. Kim and E. Abraham, Involvement of reactive oxygen species in tolllike receptor 4-dependent activation of NF- $\kappa \mathrm{B}, \mathrm{J}$. Immunol., 2004, 172(4), 2522-2529, DOI: 10.4049/ jimmunol.172.4.2522.

41 B. C. B. Boaventura, E. L. da Silva, R. H. Liu, E. S. Prudencio, P. F. Di Pietro, A. M. Becker and R. D. de M. C. Amboni, Effect of yerba mate (Ilex paraguariensis A. St. Hil.) infusion obtained by freeze concentration technology on antioxidant status of healthy individuals, LWT-Food Sci. Technol., 2015, 62, 948-954, DOI: 10.1016/j. lwt.2015.02.028.

42 D. Askaripour, Green Tea vs Yerba Mate - Circle of Drink. Retrieved December 7, 2018, from https:/circleofdrink. com/green-tea-vs-yerba-mate. 
43 G. de A. Gonçalves, A. B. de Sá-Nakanishi, M. M. N. Wendt, J. F. Comar, C. A. Bersani Amado, A. Bracht and R. M. Peralta, Green tea extract improves the oxidative state of the liver and brain in rats with adjuvant-induced arthritis, Food Funct., 2015, 6(8), 2701-2711, DOI: 10.1039/c5fo00548e.

44 M. Serafini, D. Del Rio, D. N'Dri Yao, S. Bettuzzi and I. Peluso, Herbal medicine: biomolecular and clinical aspects, in Herbal Medicine: Biomolecular and Clinical Aspects, ed. F. F. Benzie and S. Wachtel-Galor, CRC Press, Boca Raton-USA, 2011, p. 473.

45 R. Singh, N. Akhtar and T. M. Haqqi, Green tea polyphenol epigallocatechin-gallate: inflammation and arthritis, Life Sci., 2010, 86(25-26), 907-918, DOI: 10.1016/j. lfs.2010.04.013. 